\title{
Effect of Monochromatic Infrared Energy Light Versus Laser Therapy in Diabetic Peripheral Neuropathy
}

\author{
ELHAM MOHAMED YOUSIEF, M.D.*; SAHIER OMAR EL-KHASHAB, M.D.*; \\ MOHAMED HUSSEIN EL GENDY, M.D.**; RABAB ALI MOHAMED, M.D.** and \\ EMAN ABD EL KHALEK ELSIOFY MOHAMED, M.Sc.**
}

The Department of Internal Medicine, Faculty of Medicine* and Department of Physical Therapy for Basic Science, Faculty of Physical Therapy**, Cairo University, Egypt

\begin{abstract}
Diabetic peripheral neuropathy (DPN) is known to be a severe longterm sequelae of diabetes mellitus (DM) and correlated with high morbidity and mortality. There's no widely agreed optimal method for its treatment. Monochromatic Infrared Photo Energy (MIRE) and Low Level Laser Therapy) LLLT) are relatively new modalities of light used to boost the velocity of nerve conduction (NCV), minimize pain and increase peripheral circulation.

Purpose: The objective of this study was to compare the effect MIRE versus LLLT in DPN on NCV, pain, and daily living function (ADL) activity.

Material and Methods: Thirty patients with DPN, type 2 diabetes (T2DM) with neuropathic pain, particularly in the lower limbs, were recruited at $(56.29 \pm 2.98)$ years of age. Any of the patients had 10 to 15 years of DM. They were split into two groups: Group A (15 patients) had MIRE applied to each limb for 40 minutes. Group B (15 patients) had LLLT applied to each limb for 20 minutes. All patients were subjected to various physical assessment tests, including a questionnaire on NCV, pain and quality of life (QOL), both assessed before and after treatment.
\end{abstract}

Results: Significant changes in NCV, pain and functional ADL $(p<005)$ have been reported in each community following treatment. However, there were no significant differences between the 2 posttreatment groups $(p>0.05)$.

Conclusion: MIRE and LLLT are both effective in improving deep peroneal nerve neuronal activity, decreasing pain and improving activity of daily living (ADL) in DPN.

Key Words: Diabetic peripheral neuropathy - Low level laser Therapy - Monochromatic infrared energy - Nerve conduction velocity - Quality of life.

Correspondence to: Dr. Elham Mohamed Yousief, The Department of Internal Medicine, Faculty of Medicine, Cairo University, Egypt

\section{Introduction}

DIABETIC peripheral neuropathy (DPN) is considered one of the most severe long-term microvascular sequalae of diabetes mellitus (DM) that affects up to 50 percent of patients with diabetes (Edwards et al., 2014). It is a late finding for type $1 \mathrm{DM}$ but could be an early finding for type $2 \mathrm{DM}$ (T2DM) (Verrotti et al. 2014).

While it affects all nerve fibers, small myelinated and unmyelinated Fibers that transmit pain and temperature are more affected (Clin 2015). DPN also causes disturbances in posture, foot ulceration, infection and even amputation, disturbances in sleep pattern, mood and quality of life (QOL) in addition to pain and numbness in the extremities; Both of which contribute to high health-care resource use (Prompers et al., 2008).

DPN treatment is actually only symptomatic, relieving pain only by analgesic; it is associated with side effects and will not avoid the development of the initial pathologic cycle (Leonard, Farooqi, and Myers 2004). Nonpharmacological symptomatic treatments including acupuncture (Zinman et al., 2004) static and pulsed magnetic field therapies (Tavakoli et al., 2008) and various electrotherapies (Young et al., 1992) have been suggested.

Monochromatic infrared photoenergy (MIRE) and lowlevel laser therapy (LLLT) are relatively recent types of light energy used for DPN management (Robinson et al., 2017).

How MIRE does produce its biological effects is uncertain. One theory is that hemoglobin $(\mathrm{Hb})$ 
photo stimulation enhances the release of nitric oxide (NO), leading to an improvement in blood flow (Maddigan, Feeny, and Johnson 2005). Another biological effect may be to increase the cell metabolism by stimulating the production of mitochondrial adenosine triphosphate (ATP) (Vsm, Sofat and Kumar s.d.). The LLLT mechanism of action is related to the cell's ability to affect normal ATP production by absorbing the photon and converting the energy into ATP by forming singlet oxygen, reactive oxygen species or NO (Harkless et al., n.d.).

This study aimed to compare the effect of MIRE versus that of LLLT on the velocity of nerve conduction (NCV), pain and activity of daily living $(\mathrm{ADL})$ in DPN.

\section{Subjects and Methods}

\section{Study population and study design patients and methods:}

This prospective cohort study was conducted in 30 patients (13 males and 17 females) with type $2 \mathrm{DM}$ for 10 to 15 years, mainly with DPN in the lower limbs. All had their blood sugar regulated on oral hypoglycemic drugs with a HbA1C varying from 6 per cent to 7 per cent. The age of the patients ranged between 50 and 65 years. They all suffered clinically from glove and stock numbness, hypoesthesia, burning pain, foot spasm and lower limb muscle weakness.

Patients with severe intolerable pain, non-DM neuropathy, musculoskeletal deformities, severe cognitive dysfunction, other neurological problems such as hemiplegia, unstable heart disease, uncontrolled hypertension and insulin dependent diabetes mellitus were excluded from the study. Patients were recruited from the Faculty of Physical Therapy's ambulatory clinic and the Coptic Hospital. Prior to the analysis, the protocol was appropriately guided and an informed written consent form from all participants was obtained.

The research procedure conformed to the ethical principles of the Helsinki Declaration of 1975, and was accepted by the Internal Medicine Department's Local Ethical Committee, Cairo University. Subjects were randomly divided into two groups: Group A (15 patients) received MIRE and LLLT received in Group B (15 patients). For MIRE, Anodyne therapy system (ATS) a noninvasive, drug free device that delivers MIRE through infrared light emitting diode, with a wave length of
$890 \mathrm{~nm}$, that are mounted in flexible therapy pads was used. Pads contain infrared diode (electronic devices with two electrodes) that emit pulsed nearinfrared irradiation was placed on the skin(Profile 2015). (Maddigan et al., 2005). Patients received three sessions per week, for 12 sessions for a duration of 40 minutes per session. Pads were placed in direct contact with 4 pads, 2 for each foot one on forefoot and other on heel and cables connected to the base unit (Michael J. Aminoff, M.D., D.Sc. 2012).

Laser form was used in FotLLL, ASA Laser Bravo Terza Series. The system emits a mixed light (HeNe wavelength $632.8 \mathrm{~nm}$, continuous and IR wave length $780905 \mathrm{~nm}$, pulsed) with both helium neon and infrared (IR) laser. The system discharges, in a carefully regulated and recommended manner, a uniform irradiation of a fairly wide area (Khanna et al., 2012) [18]

For 12 sessions, the patients received three sessions per week. The patient was placed in a supine lying position, completely relaxed and supported by alcohol washing the area of the laser application on the leg and foot.Laser radiation delivery continued for $20 \mathrm{~min}$. The energy at 10 joules/cm was measured and the frequency was $2600 \mathrm{~Hz}$ (Michael J. Aminoff, M.D., D.Sc. 2012).

Neuropack plus version 1.59, NHON KOHDEN was selected with a four-channel electrode diagnostic device and designed amplifier to test NCV amplitude, distal deep peroneal nerve latency for both lower limbs (Lavery et al., 2008).

Peroneal NCV was measured with standard electrodes at the surface. The active electrode was positioned over the anterolateral part of the foot's proximal mid tarsal region, and the reference electrode was placed on the small toe and the ground electrode on the lateral or medial malleolus (Gilchrist and Sachs 2004).

VAS (Visual analog scale) was used to measure the severity of perceived pain. A $10-\mathrm{cm}$ line was given to the patient and he was asked to draw on the line the pain severity he experienced. The left end of the line was "no pain at all," and the right end of the line was "the worst pain you can imagine". The position of the patient on the line was then measured with a ruler (in centimetres).

The VAS has been considered a reliable and accurate instrument for quantifying perceived pain (Bjordal et al., 2008). 
QOL was measured by a score of 39/D39, consisting of 39 items in five domains: Energy and mobility (15 items), diabetic control (12 items), anxiety and worry (4 items), social and peer burden (5 items), and sexual function (3 items) (Masakado et al., 2008). Patients were assessed before and after 12 treatment program's sessions.

Data were interpreted statistically in the form of a mean, standard deviation mean $\pm \mathrm{SD}$, using descriptive statistics. Statistical research was performed using version 20 of SPSS for Windows (SPSS, Inc., Chicago, IL). MANOVA was used to distinguish between the two classes by using inferential statistics in the form of 2 ambient mixed architecture. For all measures the degree of significance was 0.05 .

\section{Results}

There was no statistically significant difference $(p>0.05)$ between the two studied groups as regards all demographic and clinical pretreatment data (Table 1).

The mean VAS values \pm SD pre and posttreatment were $7.5 \pm 1.01$ and $2.35 \pm 0.49$ for group (A) $(p$-value $=0.0001 *)$ and $7.78 \pm 0.89$ and $2 \pm 0.55$ for group $(\mathrm{B})$ respectively $(p$-value $=0.0001 *)$.

The mean QOL scale values \pm SD pre and posttreatment were $4.62 \pm 0.16$ and $7.44 \pm 0.17$ in group $\mathrm{A}(p$-value $=0.0001 *)$ and $4.60 \pm 0.16$ and $7.46 \pm 0.17$ in group $\mathrm{B}(p$-value $=0.0001 *)$ respectively.

$\mathrm{NCV}$ mean values \pm SD preand posttreatment were $8.02 \pm 3.6$ and $41.25 \pm 2.71$ in group A ( $p$-value $=0.0001 *)$ and $40.44 \pm 2.77$ and $42.77 \pm 1.95$ in group B $(p$-value $=0.0001 *)$, respectively.
The initial pretreatment measurements obtained from all patients in both groups showed that there was no statistically significant difference between the two groups with respect to NCV of the deep peroneal nerve, VAS, Diabetic D39 QLS.

Following the application of the MIRE to group A and the LLLT to group B (post-treatment), there was a significant improvement in NCV (amplitude, distal latency and conductive velocity) of deep peroneal nerve in both feet, decrease in pain intensity rates in both feet, and an extremely significant improvement in functional ADL provided by VAS and QOL in groups A and B.

Multiple pairwise comparison tests (Post hoc tests) revealed that there was no significant difference of the mean values of the "post" test between both groups regarding VAS, QOL and NCV with $(p=0.084)(p=0.747)(p=0.102)$, respectively.

The application of the DPN physical therapy system to two groups showed significant difference across all variables. For each group (A and B) there was statistically significant difference between pre- and posttreatment but there was no statistically significant difference between groups (A and B).

Table (2) displays the effects of dependent sample $t$-tests comparing pain, QOL scale and $\mathrm{NCV}$ outcomes pre to 4 weeks within the intervention groups. These results show that in each category there are statistically significant changes in $\mathrm{NCV}$, pain, and functional ADL $(p<005)$. After 12 weeks of counseling, however, no major variations were reported between the two treatment modes after 12 weeks of therapy $(p>0.05)$.

Table (1): Demographic date of group and group B.

\begin{tabular}{lllllll}
\hline \multirow{2}{*}{ Items } & \multicolumn{1}{c}{ Group A } & Group B & \multicolumn{2}{c}{ Comparison } & \\
\cline { 2 - 5 } & Mean \pm SD & Mean \pm SD & $t$-value & $p$-value & \\
\hline Age (yrs) & $56.06 \pm 2.81$ & $56.33 \pm 3.15$ & -0.244 & 0.809 & NS \\
Body mass (Kg) & $91.2 \pm 6.06$ & $91 \pm 5.52$ & 0.094 & 0.925 & NS \\
Height (cm) & $169 \pm 9.58$ & $166.86 \pm 7.56$ & 0.677 & 0.504 & NS \\
Duration of illness (5-15 years) & $11.13 \pm 2.19$ & $10.8 \pm 2.24$ & 0.877 & 0.411 & NS \\
\hline
\end{tabular}


Table (2): Comparison between group A and group B before after treatment.

\begin{tabular}{|c|c|c|c|c|c|c|}
\hline & & Pre treatment & Post treatment & \multirow{2}{*}{ MD } & \multirow{2}{*}{$\%$ of change } & \multirow{2}{*}{$p$-value } \\
\hline & & Mean \pm SD & Mean \pm SD & & & \\
\hline VAS & $\begin{array}{l}\text { Group A } \\
\text { Group B } \\
\text { MD } \\
p \text {-value }\end{array}$ & $\begin{array}{l}7.5 \pm 1.01 \\
7.78 \pm 0.89 \\
-0.28 \\
0.437\end{array}$ & $\begin{array}{l}2.35 \pm 0.49 \\
2 \pm 0.55 \\
0.35 \\
0.084\end{array}$ & $\begin{array}{l}5.14 \\
5.78\end{array}$ & $\begin{array}{l}68.5 \\
74.2\end{array}$ & $\begin{array}{l}0.0001^{*} \\
0.0001^{*}\end{array}$ \\
\hline Quality Life Scale & $\begin{array}{l}\text { Group A } \\
\text { Group B } \\
\text { MD } \\
p \text {-value }\end{array}$ & $\begin{array}{l}4.62 \pm 0.16 \\
4.60 \pm 0.16 \\
0.02 \\
0.824\end{array}$ & $\begin{array}{l}7.44 \pm 0.17 \\
7.46 \pm 0.17 \\
-0.02 \\
0.747\end{array}$ & $\begin{array}{l}-2.82 \\
-2.85\end{array}$ & $\begin{array}{l}61 \\
62\end{array}$ & $\begin{array}{l}0.0001^{*} \\
0.0001^{*}\end{array}$ \\
\hline $\begin{array}{l}\text { Amplitude of right deep } \\
\text { peroneal nerve }\end{array}$ & $\begin{array}{l}\text { Group A } \\
\text { Group B } \\
\text { MD } \\
p \text {-value }\end{array}$ & $\begin{array}{l}1.1 \pm 0.21 \\
1.29 \pm 0.27 \\
-0.19 \\
0.051\end{array}$ & $\begin{array}{l}1.7 \pm 0.36 \\
1.8 \pm 0.36 \\
-0.1 \\
0.473\end{array}$ & $\begin{array}{l}-0.6 \\
-0.5\end{array}$ & $\begin{array}{l}54.5 \\
38.75\end{array}$ & $\begin{array}{l}0.0001^{*} \\
0.0001^{*}\end{array}$ \\
\hline $\begin{array}{l}\text { Amplitude of left deep } \\
\text { peroneal nerve }\end{array}$ & $\begin{array}{l}\text { Group A } \\
\text { Group B } \\
\text { MD } \\
p \text {-value }\end{array}$ & $\begin{array}{l}1.1 \pm 0.57 \\
1.12 \pm 0.46 \\
-0.02 \\
0.929\end{array}$ & $\begin{array}{l}1.93 \pm 0.64 \\
1.87 \pm 0.53 \\
0.06 \\
0.786\end{array}$ & $\begin{array}{l}-0.83 \\
-0.75\end{array}$ & $\begin{array}{l}75.4 \\
67\end{array}$ & $\begin{array}{l}0.0001^{*} \\
0.0001^{*}\end{array}$ \\
\hline $\begin{array}{l}\text { Distal latency of right deep } \\
\text { peroneal nerve }\end{array}$ & $\begin{array}{l}\text { Group A } \\
\text { Group B } \\
\text { MD } \\
p \text {-value }\end{array}$ & $\begin{array}{l}6.1 \pm 0.70 \\
6.09 \pm 0.61 \\
0.01 \\
0.957\end{array}$ & $\begin{array}{l}4.76 \pm 0.73 \\
4.84 \pm 0.52 \\
-0.08 \\
0.742\end{array}$ & $\begin{array}{l}1.34 \\
1.25\end{array}$ & $\begin{array}{l}22 \\
20.5\end{array}$ & $\begin{array}{l}0.0001^{*} \\
0.0001^{*}\end{array}$ \\
\hline $\begin{array}{l}\text { Distal latency of left deep } \\
\text { peroneal nerve }\end{array}$ & $\begin{array}{l}\text { Group A } \\
\text { Group B } \\
\text { MD } \\
p \text {-value }\end{array}$ & $\begin{array}{l}6.15 \pm 0.91 \\
5.89 \pm 0.77 \\
0.26 \\
0.422\end{array}$ & $\begin{array}{l}4.89 \pm 0.69 \\
4.77 \pm 0.70 \\
0.12 \\
0.653\end{array}$ & $\begin{array}{l}1.26 \\
1.11\end{array}$ & $\begin{array}{l}20.5 \\
18.8\end{array}$ & $\begin{array}{l}0.0001^{*} \\
0.0001^{*}\end{array}$ \\
\hline $\begin{array}{l}\text { Nerve conduction velocity of } \\
\text { right deep peroneal nerve }\end{array}$ & $\begin{array}{l}\text { Group A } \\
\text { Group B } \\
\text { MD } \\
p \text {-value }\end{array}$ & $\begin{array}{l}38.02 \pm 3.6 \\
40.44 \pm 2.77 \\
-2.41 \\
0.058\end{array}$ & $\begin{array}{l}41.25 \pm 2.71 \\
42.77 \pm 1.95 \\
-1.51 \\
0.102\end{array}$ & $\begin{array}{l}-3.22 \\
-2.32\end{array}$ & $\begin{array}{l}8.4 \\
5.7\end{array}$ & $\begin{array}{l}0.0001^{*} \\
0.0001^{*}\end{array}$ \\
\hline $\begin{array}{l}\text { Nerve conduction velocity of } \\
\text { left deep peroneal nerve }\end{array}$ & $\begin{array}{l}\text { Group A } \\
\text { Group B } \\
\text { MD } \\
p \text {-value }\end{array}$ & $\begin{array}{l}36.86 \pm 2.54 \\
38.12 \pm 4.72 \\
-1.26 \\
0.386\end{array}$ & $\begin{array}{l}40.6 \pm 2.23 \\
42.34 \pm 1.90 \\
-1.74 \\
0.035^{*}\end{array}$ & $\begin{array}{l}-3.73 \\
-4.21\end{array}$ & $\begin{array}{l}10.11 \\
11.04\end{array}$ & $\begin{array}{l}0.0001^{*} \\
0.0001^{*}\end{array}$ \\
\hline
\end{tabular}

\section{Discussion}

DM is a metabolic condition described as hyperglycemia due to insulin secretion abnormality, action or both (Hunt 2011). This chronic hyperglycemia is associated with longterm damage to multiple organs, in particular to the skin, kidneys, nerves, heart and blood vessels (Boulton et al., 2005). Strict regulation of DM is the only tested solution to preventing DPN and its complications (Farmer, Li, and Dobrowsky, 2012). When DPN is established there are few clear treatment approaches available (Kazemi-Khoo, 2006).

The current study aimed to compare the effects of MIRE versus LLLT on NCV, pain and functional ADL in DPN. Regarding MIRE, the results revealed that there was a significant reduction in VAS, increase of QOL scale and increase of NCV post treatment $(p$-value $=0.0001)$. This was found in agreement with Harkless et al., who reviewed the medical records of 2239 patients with proven DPN to decide if MIRE was associated with increased sensitivity to the foot and reduced neuropathic pain. Their findings showed an increase of 66 percent in the number of needless regions, 53 percent no longer had protective sensation loss and 67 percent had VAS pain reduction (Harkless et al. n.d.). Tarek Ahmed et al., 2012 examined the impact of MIRE on pain relief, sensation enhancement, and improved DPN control and showed statistically significant changes in all after 12 sessions (Ammar 2012). Kochman et al., recorded that most DPN subjects had improved sensation after 6 MIRE sessions, and after 12 treatments, no subject continued to experience an absent sensation of hot/cold (HC) (Kochman, Carnegie, and Burke 2002).

Powell et al. (2004) also published on 68 ageing DPN patients to decide whether restoring sensation via MIRE would minimize foot ulcer incidence. 
The recorded incidence of recent foot wounds after an average period of 12.5 months was 1.5 percent compared to the estimated incidence of 7.3 percent in the Medicare population $(p<.0001)$ (Powell, Carnegie, and Burke n.d.).

The American Medical Association (2008) supporting these results showed that after MIRE, the sensory loss at the foot had greatly improved by 400 percent vs 40 percent after placebo. This percentage difference or factor had infused confidence that lower amputation of the extremity could potentially be avoided (Anon n.d).

MIRE facilitates healing of diabetic foot ulcers by increasing $\mathrm{NO}$ concentration in the blood stream, inducing dilation in the foot blood vessels (James et al., 2004). Chen et al., found evidence that NO release occurs after exposure to low levels of red and near IR light. MIRE tends to speed up healing at places where the MIRE pad is located (Chen et al., 2011). Chukuka (2004) demonstrated that light energy is consumed especially in the mitochondria by endogenous chromophores and used for the synthesis of ATP. This ATP is then used to drive metabolic processes required to repair or regenerate components of cells and tissues [37]. Burke et al., 2003 showed an increase in microcirculation, calculated at the surface of the skin using a scanning laser Doppler; the increase starts within min of MIRE exposure, is significant (10-fold increase) after 20-30min and persists for up to one hour (Burke 2003). Unlike these results, Clifft etal showed in 2005 that MIRE did not provide improvement in peripheral sensation compared to sham treatment. Results showed that from stage 1 to stage 2 , there was a substantial sensory change of 5.07 SWM but no further important variations between sham and active care. They thus concluded that MIRE was no more effective than placebo and that MIRE was an unreliable modality in sensory dysfunction (Clifft et al., 2005). Additionally, Lavery et al., used the threshold of vibration perception (VPT) as a method for distinguishing between sham and active therapy. For 90 days 60 patients were able to complete the course at 40 minutes a day They also concluded that MIRE was no more effective in treating sensory neuropathy than placebo therapy (Lavery et al., 2008). Nawfar et al., 2011 performed a randomized controlled, single blinded study where neuropathy was tested using MNSI, accompanied by a neurometer assessment of the current perception threshold For a total of 12 injections, both feet were randomized to get either daily MIRE or placebo treatment. Data showed no substantial change in diabetic patients with neuropathic feet (Nawfar and Yacob 2011).
In terms of LLLT tests, our analysis also showed a substantial reduction in VAS, an improvement in the QOL scale and an improvement in posttreatment NCV $(p$-value $=0.0001)$.

Such findings are consistent with Abeer et al. (2014), who researched pain and decreased NCV in 30 DPN patients. They measured peak static and dynamic plant strain, peroneal NCV, amplitude and degree of pain before and after $\mathrm{He}-\mathrm{Ne}$ laser on the foot planter surface and lumbosacral region. They find LLLT to be successful in improving $\mathrm{NCV}$, relieving pain and redistributing the pressure of foot plantar in painful DPN (Yamany and Sayed 2012).

Cg et al., observed substantial reductions in pain using the VAS scale and large rises in temperature from baseline to post-intervention LLLT in DPN (Cg et al., 2015). Rochkind found that laser enhanced the regeneration and recruitment of voluntary muscle function when applied transcutaneously to the nerve damage site (15min) and the corresponding spinal cord segments (15min). An fascinating hypothesis may be that the change in cutaneous blood flow could be replicated at the endoneural level by a similar trend, indicating that an increase in nerve blood flow may be a mechanism by which laser causes peripheral nerve function change (Rochkind 2009).

Carmelie has shown that the blood vessels and nerves use similar signals and principles to distinguish, expand and probably react synergistically to specific stimuli such as laser (Carmeliet 2003). Azovic et al. (2014) reported a significant improvement in sensory nerve velocity(SNV), sensory and motor distal latencies after treatment with $830 \mathrm{~nm}$ and $780 \mathrm{~nm} \mathrm{He}-\mathrm{Ne}$ LLLT with intensity $3.6 \mathrm{~J} / \mathrm{cm}^{2}$ and $2.7 \mathrm{~J}, 3.4 \mathrm{~J} / \mathrm{cm}^{2} /$ point respectively in patients with carpal tunnel syndrome (Lazovic et al., 2014).

Perić et al., indicated that LLLT had no significant direct effect on the peroneal nerve and ulnar nerve SCV and NCV of the DPN patients. This may be explained by the fact that they used a pointer laser with a wavelength of $904 \mathrm{~nm}$; which is stated to have no impact on the electrophysiological parameters of either sensory or motor function in normal and injured sciatic nerve (Peri and Cvetkovi 2006). It's not known the exact mechanism by which LLLT relieves pain. In vivo and in vitro studies have shown that $830 \mathrm{~nm}$ lasers inhibit nerve fiber transmission, given the etiology for DPN pain via abnormal activation of weakened nerve fibers, it could require regenerating small diameter nociceptive fibres Laser therapy in the somatotopically associated dorsal horn should 
block the irregular activity in the affected peripheral nerve, or block neurotransmission (Bjordal et al., 2008). Anders et al., suggested that LLT causes massive axonal sprouting and stimulates Schwann cell proliferation, which are key factors in successful nerve recovery (Anders, Geuna, and Rochkind 2004). Suggested mechanism of laser may be Increased activity of certain cells, such as leukocytes and phagocytes with increased calcium in the cell cytoplasm, association with cytochromes and stimulation of redox activity in the cell respiratory chain, resulting in cell activation, accelerated cell division and development, activation of protein, cytokine synthesis, Stimulation of ATP production, which increases the mitotic function of the cells; and relaxation of the vessel walls (vasodilatation) by photolysis of complexes such as nitric oxide may be suggested. (Klebanov et al., 2001).

Bingol et al., who tested therapeutic efficacy of LLLT in 40 patients with shoulder pain and found no significant change in laser group pain, active range and algometric sensitivity compared to controls (Bingöl, Altan, and Yurtkuran 2005), published contradictory results.

Similarly, Zinman et al., reported that LLLT had no effect on the Toronto Clinical Neuropathy Score, sympathetic skin response or quantitative sensory testing and concluded that their findings did not provide statistically relevant evidence to support LLLT for the treatment of painful symptoms as patients with DPN (Zinman et al., 2004).

After MIRE and LLLT a statistically significant improvement was noted in both groups in all parameters whether pain, sensation or nerve conduction. Nonetheless Multiple pairwise comparison tests hoc tests) showed no substantial difference between the two groups with respect to VAS, QOL and NCV $(p=0.084)(p=0.747)(p=0.102)$, respectively; giving neither line of treatment an edge over the other in the treatment of DPN. However, combining both treatment lines could be an area for future studies, with the goal of producing better outcomes.

\section{Conclusion:}

MIRE and LLLT are important treatment modalities for DPN; help to relieve discomfort, and enhance sensation, muscle power, and NCV. This study concluded that both treatment lines would enhance neural function lost in DPN, but there is no proof of statistically meaningful superiority of one modality over the other. The combination of both for further progress in DPN physical therapy services may be an idea for future study.

\section{References}

1- AMMAR, TAREK A.: "Monochromatic Infrared Photo Energy in Diabetic Peripheral Neuropathy". ISRN Rehabilitation, 1-8, 2012.

2- ANDERS, JUANITA J., STEFANO GEUNA and SHIMON ROCHKIND: "Phototherapy Promotes Regeneration and Functional Recovery of Injured Peripheral Nerve". Neurological Research, 26 (2): 233-39. Retrieved (http://www.ncbi.nlm.nih.gov/pubmed/15072645), 2004.

3- ANON. N.D.: "Consensus Statement: Report and Recommendations of the San Antonio Conference on Diabetic Neuropathy. American Diabetes Association American Academy of Neurology". Diabetes Care, 11 (7): 592-97. Retrieved (http://www.ncbi.nlm.nih.gov/pubmed/ 3060328).

4- ASZMANN O.C., KRESS K.M. and DELLON A.L.:"Results of Decompression of Peripheral Nerves in Diabetics: A Prospective, Blinded Study". Plastic and Reconstructive Surgery 106 (4): 816-22. Retrieved (http://www.ncbi. nlm.nih.gov/pubmed/11007394), 2000.

5- BINGÖL, UMIT, LALE ALTAN and MERIH YURTKURAN: "Low-Power Laser Treatment for Shoulder Pain". Photomedicine and Laser Surgery 23 (5): 45964. Retrieved (http://www.ncbi.nlm.nih.gov/ pubmed/16262574), 2005.

6- BJORDAL, JAN M., et al.: “A Systematic Review with Procedural Assessments and Meta-Analysis of Low Level Laser Therapy in Lateral Elbow Tendinopathy (Tennis Elbow)". BMC Musculoskeletal Disorders 9:75. Retrieved (http://www.ncbi.nlm.nih.gov/pubmed/18510742), 2008.

7- BOULTON, ANDREW J.M., et al.: "Diabetic Neuropathies: A Statement by the American Diabetes Association". Diabetes Care, 28 (4): 956-62. Retrieved (http://www. ncbi.nlm.nih.gov/pubmed/15793206), 2005.

8- BURKE, THOMAS J.: "5 Questions--and Answers--about MIRE Treatment". Advances in Skin \& Wound Care 16 (7): 369-71. Retrieved (http://www.ncbi.nlm.nih. . gov/pubmed/14688646), 2003.

9- CARMELIET, PETER: "Blood Vessels and Nerves: Common Signals, Pathways and Diseases". Nature Reviews. Genetics, 4 (9): 710-20. Retrieved (http://www. ncbi.nlm.nih.gov/pubmed/12951572). 2003.

10- CG, SHASHI KUMAR, et al.: "Efficacy of Low Level Laser Therapy on Painful Diabetic Peripheral Neuropathy". Laser Therapy, 24 (3): 195-200. Retrieved (http://www. . ncbi.nlm.nih.gov/pubmed/26557734), 2015.

11- CHEN, AARON C.H., et al.: "Low-Level Laser Therapy Activates NF-kB via Generation of Reactive Oxygen Species in Mouse Embryonic Fibroblasts". PloS One, 6 (7): e22453. Retrieved (http://www.ncbi.nlm.nih. . gov/pubmed/21814580), 2011.

12- CLIFFT, JUDY K., RICHARD J. KASSER, TIMOTHY S. NEWTON and ANDREW J. BUSH: "The Effect of Monochromatic Infrared Energy on Sensation in Patients with Diabetic Peripheral Neuropathy: A Double-Blind, Placebo-Controlled Study". Diabetes Care, 28 (12): 28962900. Retrieved (http://www.ncbi.nlm.nih. . gov/pubmed/16306551), 2005.

13- CLIN, HAND: "Peripheral Nerve Trauma: Mechanisms of Injury and Recovery", 29 (3): 317-30, 2015. 
14-EDWARDS, JAMES L., ANDREA VINCENT, THOMAS CHENG and EVA L. FELDMAN: "Diabetic Neuropathy: Mechanisms to Management”, 120 (1): 1-34, 2014.

15- FARMER, KEVIN L., CHENGYUAN LI and RICK T. DOBROWSKY: "Diabetic Peripheral Neuropathy: Should a Chaperone Accompany Our Therapeutic Approach?" Pharmacological Reviews, 64 (4): 880-900. Retrieved (http://www.ncbi.nlm.nih.gov/pubmed/22885705), 2012

16- GILCHRIST, JAMES M. and GEORGE M. SACHS: "Electrodiagnostic Studies in the Management and Prognosis of Neuromuscular Disorders". Muscle \& Nerve, 29 (2): 165-90. Retrieved (http://www.ncbi.nlm.nih. . gov/pubmed/14755481), 2004.

17- HARKLESS, LAWRENCE B., SALVATORE DELELLIS, DALE H. CARNEGIE, and THOMAS J. BURKE. N.D.: "Improved Foot Sensitivity and Pain Reduction in Patients with Peripheral Neuropathy after Treatment with Monochromatic Infrared Photo Energy MIRE”. Journal of Diabetes and Its Complications, 20 (2): 81-87. Retrieved (http://www.ncbi.nlm.nih.gov/pubmed/16504836).

18- HUNT, DERECK L.: "Diabetes: Foot Ulcers and Amputations". BMJ Clinical Evidence 2011. Retrieved (http://www.ncbi.nlm.nih.gov/pubmed/21871137), 2011.

19- JAMES, PHILIP E., DEREK LANG, TIMOTHY TUFNELL-BARRET, ALEX B. MILSOM and MICHAEL P. FRENNEAUX: "Vasorelaxation by Red Blood Cells and Impairment in Diabetes: Reduced Nitric Oxide and Oxygen Delivery by Glycated Hemoglobin". Circulation Research, 94 (7): 976-83. Retrieved (http://www.ncbi.nlm.nih. gov/pubmed/14963010), 2004.

20- KAZEMI-KHOO N.: "Successful Treatment of Diabetic Foot Ulcers with Low-Level Laser Therapy". Foot, 16 (4): 184-87, 2006.

21- KHANNA, ABHINAV, et al.: "Hemoglobin A1c Improvements and Better Diabetes-Specific Quality of Life among Participants Completing Diabetes Self-Management Programs: A Nested Cohort Study". Health and Quality of Life Outcomes 10: 48. Retrieved (http://www.ncbi.nlm.nih. . gov/pubmed/22583609). 2012.

22- KLEBANOV G.I., KREININA M.V., POLTANOV E.A., KHRISTOFOROVA T.V. and VLADIMIROV Y.A.: "Mechanism of Therapeutic Effect of Low-Intensity Infrared Laser Radiation." Bulletin of Experimental Biology and Medicine, 131 (3): 239-41. Retrieved (http://www.ncbi.nlm.nih.gov/ pubmed/11427908), 2001.

23- KOCHMAN, ALAN B., DALE H. CARNEGIE and THOMAS J. BURKE: "Symptomatic Reversal of Peripheral Neuropathy in Patients with Diabetes". Journal of the American Podiatric Medical Association, 92 (3): 125-30. Retrieved (http://www.ncbi.nlm.nih.gov/ pubmed/11904323), 2002.

24- LAVERY, LAWRENCE A., DOUGLAS P. MURDOCH, JAYME WILLIAMS and DAVID C. LAVERY: "Does Anodyne Light Therapy Improve Peripheral Neuropathy in Diabetes? A Double-Blind, Sham-Controlled, Randomized Trial to Evaluate Monochromatic Infrared Photoenergy". Diabetes Care, 31 (2): 316-21. Retrieved (http://www.ncbi.nlm.nih. gov/pubmed/17977931), 2008.

25- LAZOVIC, MILICA, et al.: "Placebo-Controlled Investigation of Low-Level Laser Therapy to Treat Carpal Tunnel Syndrome". Photomedicine and Laser Surgery, 32 (6):
336-44. Retrieved (http://www.ncbi.nlm.nih.gov/ pubmed/24905929), 2014.

26- LEONARD, DAVID R., M. HAMED FAROOQI and SARA MYERS: "Restoration of Sensation, Reduced Pain, and Improved Balance in Subjects with Diabetic Peripheral Neuropathy: A Double-Blind, Randomized, PlaceboControlled Study with Monochromatic near-Infrared Treatment”. Diabetes Care, 27 (1): 168-72, 2004.

27- MADDIGAN, SHERI L., DAVID H. FEENY and JEFFREY A. JOHNSON: "Health-Related Quality of Life Deficits Associated with Diabetes and Comorbidities in a Canadian National Population Health Survey." Quality of Life Research: An International Journal of Quality of Life Aspects of Treatment, Care and Rehabilitation, 14 (5): 1311-20. Retrieved (http://www.ncbi.nlm.nih.gov/ pubmed/16047506), 2005.

28- MASAKADO, YOSHIHISA, et al.: "Clinical Neurophysiology in the Diagnosis of Peroneal Nerve Palsy." The Keio Journal of Medicine, 57 (2): 84-89. Retrieved (http://www.ncbi.nlm.nih.gov/pubmed/18677088), 2008.

29- MICHAEL J. AMINOFF, M.D., D.Sc., F.R.C.: "Aminoff 'S Electrodiagnosis in Clinical Neurology in Clinical". Science Direct, 289-325, 2012.

30- NAWFAR S.A. and YACOB N.B.M.: "Effects of Monochromatic Infrared Energy Therapy on Diabetic Feet with Peripheral Sensory Neuropathy: A Randomised Controlled Trial”. Singapore Medical Journal, 52 (9): 669-72. Retrieved (http://www.ncbi.nlm.nih.gov/pubmed/21947144), 2011.

31- PERI, ZORAN and BRATISLAV CVETKOVI: "Electrophysiological Evaluation of Low-intensity Laser Therapy in Patients with Diabetic Polyneuropathy Results Subjects and Methods". Medicine and Biology, 13 (1): 11-14, 2006.

32- POWELL, MARK W., DALE E. CARNEGIE and THOMAS J. BURKE N.D.: "Reversal of Diabetic Peripheral Neuropathy and New Wound Incidence: The Role of MIRE". Advances in Skin \& Wound Care, 17 (6): 295300. Retrieved (http://www.ncbi.nlm.nih.gov/ pubmed/15289717).

33- POWELL, MARK W., DALE H. CARNEGIE and THOMAS J. BURKE: "Reversal of Diabetic Peripheral Neuropathy with Phototherapy (MIRE) Decreases Falls and the Fear of Falling and Improves Activities of Daily Living in Seniors". Age and Ageing, 35 (1): 11-16. Retrieved (http://www.ncbi.nlm.nih.gov/pubmed/16303775), 2006.

34- PROFILE, PROGRAM: “A Combined Treatment Protocol for Patients With Diabetic Peripheral Neuropathy”. (September), 68-73, 2015.

35- PROMPERS L., et al.: "Resource Utilisation and Costs Associated with the Treatment of Diabetic Foot Ulcers. Prospective Data from the Eurodiale Study". Diabetologia, 51 (10): 1826-34. Retrieved (http://www.ncbi.nlm.nih.gov/ pubmed/18648766), 2008.

36- ROBINSON, CAROLINE CABRAL, et al.: "Effects of Monochromatic Infrared Phototherapy in Patients with Diabetic Peripheral Neuropathy: A Systematic Review and Meta-Analysis of Randomized Controlled Trials". Brazilian Journal of Physical Therapy, 21 (4): 233-43. 
Retrieved (http://dx.doi.org/10.1016/j.bjpt.2017.05.008), 2017.

37- ROCHKIND, SHIMON: "Phototherapy in Peripheral Nerve Regeneration: From Basic Science to Clinical Study”. Neurosurgical Focus, 26 (2): E8. Retrieved (http://www.ncbi.nlm.nih.gov/pubmed/19199510), 2009.

38- TAVAKOLI, MITRA, MOAZ MOJADDIDI, HASSAN FADAVI and RAYAZ A. MALIK: "Pathophysiology and Treatment of Painful Diabetic Neuropathy". Current Pain and Headache Reports, 12 (3): 192-97. Retrieved (http://www.ncbi.nlm.nih.gov/pubmed/1 8796269), 2008.

39- VERROTTI, ALBERTO, GIOVANNI PREZIOSO, RAFFAELLA SCATTONI, and FRANCESCO CHIARELLI: "Autonomic Neuropathy in Diabetes Mellitus". Frontiers in Endocrinology, 5 (DEC): 1-7, 2014.

40- VSM, A.S. KASTHURI, S. SOFAT and N. KUMAR N.D.: "Somatic Neuropathy In Diabetes Mellitus". Medical
Journal Armed Forces India, 56 (1): 33-36. Retrieved (http://dx.doi.org/10.1016/S0377-1237(17)30087-4).

41- YAMANY, ABEER A. and HAYAM M. SAYED: "Effect of Low Level Laser Therapy on Neurovascular Function of Diabetic Peripheral Neuropathy". Journal of Advanced Research, 3 (1): 21-28. Retrieved (http://dx.doi.org/ 10.1016/j.jare.2011.02.009), 2012.

42- YOUNG, M.J., A. VEVES, M.G. WALKER and A.J. BOULTON: "Correlations between Nerve Function and Tissue Oxygenation in Diabetic Patients: Further Clues to the Aetiology of Diabetic Neuropathy?" Diabetologia, 35 (12): 1146-50. Retrieved (http://www.ncbi.nlm.nih. . gov/pubmed/1478366), 1992.

43- ZINMAN, LORNE H., et al.: "Low-Intensity Laser Therapy for Painful Symptoms of Diabetic Sensorimotor Polyneuropathy: A Controlled Trial". Diabetes Care, 27 (4): 921-24. Retrieved (http://www.ncbi.nlm.nih. . gov/pubmed/15047649), 2004.

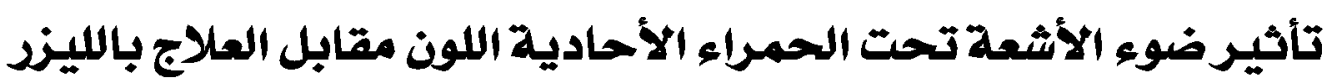

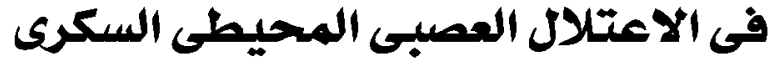

يعتبر الاعتلال العصبى المحيطى السكرى (DPN) من الأمراض الخطيرة طويلة المدى لمرض السكرى (DM) ويرتبط بارتفاع معدلات الوفيات. لا يوجد تدخل أمثل مقبول عالمياً لعلاجه ، تعد طاقة الصور بالأشعة تحت الحمراء، أحادية اللون (MIRE) والعلاج بالليزر منخفض المستوى طرق جديدة نسبياً تستخدم لتحسين سرعة التوصيل العصبى (NCV)، وتقليل الألم وزيادة الدوة الدموية الطرفية.

كان الهدف من هذه الدراسة هو المقارنة بين تأثير MIRE مقابل LLLT على NCV، والألم والنشاط الوظيفى للصياة اليومية (ADL)

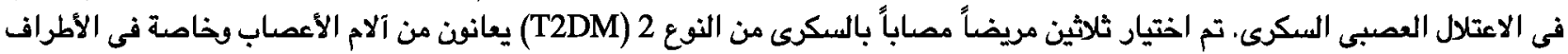

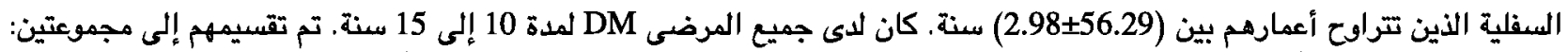

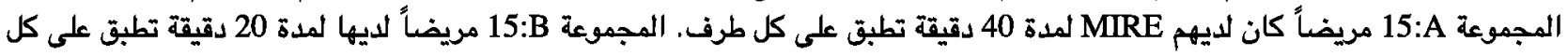

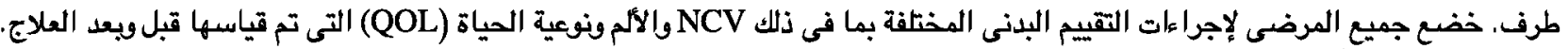

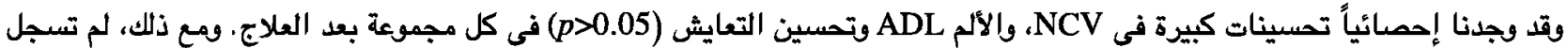

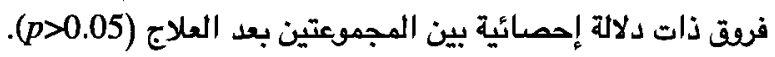

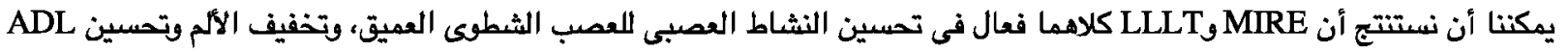
الوظيفى في DPN. 